\title{
ResearchOnline@JCU
}

This is the author-created version of the following work:

Banhalmi-Zakar, Zsuzsa, Gronow, Claire, Wilkinson, Lachlan, Bryan, Jenkins, Pope, Jenny, Squires, Geraldine, Witt, Kathy, Williams, Galina, and Womersley, Jon (2018) Evolution or revolution: where next for impact assessment?. Impact Assessment and Project Appraisal, 36 (6) pp. 506-515.

Access to this file is available from:

https://researchonline.jcu.edu.au/55280/

Copyright @ 2018 IAIA.

Please refer to the original source for the final version of this work: 


\section{Evolution or Revolution: Where next for Impact Assessment?}

Banhalmi-Zakar, Zsuzsa ${ }^{1}$, Gronow, Claire², Wilkinson, Lachlan ${ }^{3}$, Jenkins, Bryan $^{4}$, Pope, Jenny ${ }^{5,6,7}$, Squires, Geraldine ${ }^{8}$, Witt, Kathy ${ }^{9}$, Williams,

Galina $^{10}$, Womersley, Jon ${ }^{11}$

${ }^{1}$ College of Science and Engineering, James Cook University, Townsville, Australia

ORCiD: 0000-0003-3544-9353

Twitter: @banhalmizakar

LinkedIn: https://www.linkedin.com/in/zsuzsa-banhalmi-zakar-40940331/

${ }^{2}$ Water and Environmental Management, University of Bristol, Bristol, UK

${ }^{3}$ JBS\&G, Melbourne, Australia

LinkedIn: https://www.linkedin.com/in/lachlan-wilkinson-79553017/

${ }^{4}$ School of Civil, Environmental and Mining Engineering, University of Adelaide,

Adelaide Australia

ORCiD 0000-0002-4031-101X

Email: bryan.jenkins@adelaide.edu.au

${ }^{5}$ Centre for Ecosystem Management, Edith Cowan University, Perth, Australia

${ }^{6}$ Integral Sustainability, Australia

${ }^{7}$ Unit for Environmental Science and Management, North-West University, South Africa

ORCiD: 0000-0002-0099-854X

${ }^{8}$ GHD, Brisbane, Australia

${ }^{9}$ UQ Centre for Coal Seam Gas, University of Queensland, Brisbane, Australia

${ }^{10}$ School of Business, Accounting and Law, Central Queensland University, Brisbane, Australia

${ }^{11}$ Womersley Environmental Management, Cleveland, Australia

LinkedIn: https://www.linkedin.com/in/jon-womersley-feianz-cenvp-fiml-pri-nmasaccr-d-1bb94436/

Corresponding author: Dr. Zsuzsa Banhalmi-Zakar, Zsuzsa.banhalmizakar@jcu.edu.au 


\section{Evolution or Revolution: Where next for Impact Assessment?}

Impact assessment (IA) has become one of the most prevalent environmental policy instruments today. Its introduction under the National Environmental Policy Act (US) in 1969 was revolutionary. Perhaps it is not surprising, then, that such a widely used tool has received its share of criticism, including that it fails to meet some of its fundamental goals. Over the last fifty years, IA has broadened in scope and application and embraced new techniques. It has followed evolved, but has not changed fundamentally.

We believe that IA must continue to change to meet the societal and environmental challenges of the $21^{\text {st }}$ century. But will it be enough for IA to progress through incremental change (evolution), or is a complete overhaul of impact assessment (revolution) needed? We provide some ideas as to what 'evolution' and 'revolution' may look like, but rather then offering a definitive way forward now, we invite stakeholders to present their thoughts and suggestions at the IAIA19 Annual Conference in Brisbane, which carries the same theme as the title of this article.

Keywords: environmental impact assessment; strategic environmental assessment; evolution, revolution

\section{Introduction and call to action}

When the concept of environmental impact assessment (EIA) was first introduced in 1969, via the National Environmental Policy Act of the United States, it was nothing short of revolutionary. Fifty years ago, policy-makers saw the need to balance cost benefit analysis, the dominant project decision support tool, with a new environmentally focussed tool. They introduced the requirement to assess the potential environmental impacts of proposed actions prior to deciding whether those actions should proceed, a radical approach to environmental management (Bartlett 1989). Since then, the concept of impact assessment (IA) (a term that embraces environmental, social and other forms of impact assessment) has become one of the most successful project and strategic 
assessment tools. Nearly all members of the United Nations (191 of the 193) have embedded IA in national legislation or have signed some form of international legal instrument that refers to the use of IA (Morgan 2012). This means that, fifty years on, the fundamental concept of IA is not only universally recognised, but also accepted and applied worldwide.

Despite IA's widespread adoption and delivery of a range of beneficial outcomes, a lingering dissatisfaction remains about whether it has achieved its fundamental goals. Generally, the rationale behind IA is widely accepted and many aspects of its process are regarded as successful (Glasson et al. 2012). Nevertheless, in the face of ongoing environmental degradation, both practitioners and researchers share a concern that IA is insufficient and/or fundamentally flawed. The effectiveness of impact assessment is a burgeoning field of study (see Sadler 1996; Baker and McLelland 2003; Chanchitpricha and Bond 2013; Gronow et al. 2015; Pope et al. 2018; Loomis and Dziedzic 2018), with particular concerns expressed about substantive effectiveness - does IA do what it is supposed to do? A substantial volume of literature has been produced over the years that describe the shortcomings of IA practices in a multitude of jurisdictions (see Lawrence 1997; Environment and Natural Resources Committee 2011; Arts et al. 2012; Morrison-Saunders et al. 2014; Riley 2016; Institute of Environmental Management and Assessment 2017), and we explore this body of work in more detail in Section 3. Given the apparent level of dissatisfaction in IA expressed by practitioners and in the literature, it seems that few would argue that there is no scope for further improvement of IA.

The world is a much more complex place now than it was in 1969, and issues such as climate change, urbanisation, technological innovation and others have significant implications for impact assessment (Retief et al. 2016). We call for the reform of IA to 
meet the challenges of the $21^{\text {st }}$ century now and propose that there are two ways to do this. One approach is to continue to implement small-scale, incremental modifications to existing IA systems to achieve desired changes. We term this the evolutionary approach, because it reflects the common, non-scientific (or Darwinian) definition of evolution as the gradual development of something, especially from a simple to more complex form (Oxford Dictionaries 2018). IA effectiveness studies and the periodic review of IA policies in many jurisdictions are prime examples of how evolutionary changes have been introduced (see European Commission 2012; Institute of Environmental Management and Assessment (UK) 2017; Victorian Auditor-General 2017; Department of Planning and Environment (NSW Australia) 2018; EPA (US) 2018). The alternative is the revolutionary approach, which advocates for a more robust overhaul of IA. An 'IA revolution’ calls for a complete, wide-reaching, and radical change that, by definition, typically means overthrowing the existing methodologies (systems) and establishing a new approach (Collins 2018).

The upcoming International Association of Impact Assessment (IAIA) Annual Conference in Brisbane (Australia) provides the ideal forum at which to begin the deliberation over whether IA needs evolutionary or revolutionary reform. The theme of the conference is 'Evolution or Revolution: Where next for Impact Assessment?' (also the title of this article). This theme was chosen recognising that there has not been a second revolution of IA since its introduction and that critics of IA raise fair concerns about the ability of IA to fulfil its core objectives and meet future challenges. We call on IA stakeholders from around the world to question whether IA should continue to proceed on an evolution-like path as it has for half a century, or is it time for an IA revolution? In other words, this article is a call to action as well as a warm invitation to attend IAIA19 in Brisbane. 
The article begins with a brief overview of the history of IA, arguing that the development of IA has followed an evolutionary path. It then considers the case for sustaining this path through gradual changes to IA, while the following section introduces arguments for revolutionary change. While the article seeks to speak to an international audience and draw attention to the universal problems and solutions of IA, it has a stronger emphasis on Australian solutions, as the location where the authors have expertise and where IAIA19 will be held. We finish with a discussion on what evolutionary and revolutionary changes to IA might look like, based on our knowledge of Australian practice to illustrate some ideas, but we draw no conclusion. That will be left for consideration at IAIA19.

\section{The development of impact assessment}

From its early beginnings, IA was intended to provoke wider changes in the decision-making behaviour of governments and proponents, to shift society towards lower impact development and more sustainable outcomes (Bartlett and Kurian 1999; Cashmore et al. 2004). It induced transformational change through a regulatory mandatory assessment requiring the provision of sound scientific information, the examination of alternatives, and canvassing of the views of the public and a carefully considered decision-making step (Gronow et al. 2015). IA is an action-forcing mechanism on proponents of development that is focussed on avoiding, minimising and mitigating adverse environmental effects. IA does not end with decision making; it also authorises the imposition of conditions on development and the monitoring of compliance with those conditions (Morrison-Saunders and Arts 2004). Engagement in the IA process was anticipated to induce learning among proponents, scientists, analysts, policy makers, politicians and the public (Sánchez and Mitchell 2017; JhaThakur et al. 2009) which would also lead to a transformational shift in decision- 
making with a greater emphasis on environmental and social priorities (Lawrence 1997). In essence, the introduction of IA, a regulatory mechanism to force the consideration of environmental and social implications of actions prior to decisionmaking, was nothing short of revolutionary.

The fundamental processes and practices of impact assessment that originated under NEPA (1969) will be familiar to modern IA practitioners. Most of the initial requirements of IA have been incorporated in regulations worldwide - these include provisions for screening, scoping, report preparation, consideration of alternatives and mitigation measures, a statement of residual impacts, review and comment on the draft report and an assessment and consent decision by the designated regulatory agency (Glasson et al. 2012). NEPA (1969) also laid out the required content of one of the key outputs of the IA process, the final report, often referred to as the environmental impact statement (EIS) (Table 1).

Insert Table 1 here.

EIA has been mandated in Europe since 1985, with Directive 85/337/EEC, mirroring the process steps and approach of NEPA. This Directive has been updated several times and is currently codified as Directive 2014/52/EU and has been transposed into domestic regulations in all countries of the European Union. In Australia, provisions for impact assessment exist under both Federal and State regulation. Those in Australia's national environmental law, the Environment Protection and Biodiversity Conservation Act 1999, are very similar to those initially introduced in the NEPA (1969). In this sense, the fundamental requirements of IA have not changed over time.

Although the fundamental concepts and protocols of IA have not significantly changed over the last fifty years, IA has evolved in other ways. The scope of IA has broadened from a primary focus on the biophysical environment to also embrace a 
range of other spheres (Glasson et al. 2012; Morgan 2012; Morrison-Saunders et al. 2014). The EU Directives, for example, extend to the assessment of population and human health, biodiversity, risks of major accidents and disasters and the use of natural resources and climate change aspects. This broadening of scope has given rise to a variety of associated or discipline specific assessment tools over time, which IAIA (2018) refers to as ‘sub-fields of impact assessment. These sub-fields are highly varied and include social, health, ecology, economic, technology, gender and equity impact assessment, as well as more integrated appraisal tools like cumulative impact assessment and sustainability assessment (IAIA 2018; Morgan, 2012; Vanclay 2015). Whether the various sub-fields of IA assist or hinder the achievement of the initial goal of IA advocating for the protection of biophysical environment is still debated (Morrison-Saunders and Fischer 2006; Sheate 2010). IA has also been applied in new contexts by non-traditional users, for example by affected communities themselves (Winfield 2010) and financial institutions (Banhalmi-Zakar and Larsen 2016). As a result, IA practice has expanded and diversified over time.

Like many other fields, IA has also embraced new tools and techniques that have been made possible by the revolution in information technology. These include the increasing use of GIS and various spatial data formats as well as other sophisticated modelling tools (see for e.g. Like et al. 2015; Wanderer and Herle 2015; Zhang et al. 2015; Banerjee and Ghose 2017). New approaches have also been applied in the area of public participation, moving beyond basic public review of documentation to more deliberative forms of decision-making (e.g. Hartz-Karp and Pope 2011).

Perhaps the most significant reform in IA, since it was established, has been the emergence of strategic environmental assessment, or SEA. SEA aims to integrate environmental issues into decision-making earlier than EIA, and is generally regarded 
as complementing project-level EIA (Partidario 2000; Lee and Walsh 1992). The difference between IA and SEA is that the latter applies to plans, programs and policies (hence its strategic nature), while the former is typically applied to individual projects. It is beyond the scope of this paper to give an exhaustive account of the developmental forces behind SEA, its practice, and shortcomings. The purpose of our brief discussion of SEA is merely to recognise its emergence as an important development in IA practice.

The IA process originally prescribed under NEPA (1969) was intended to apply to strategic level decisions, but this aspect of the legislation was largely neglected (Bina 2007). The introduction of the European Directive 2001/42/EU launched the concept of SEA into mainstream practice in Europe and the concept has gained momentum over time (Fundingsland et al. 2012). SEA is now practised in various forms in many parts of the world; for example, it is conducted in Australia at the Federal level under the Environment Protection and Biodiversity Conservation Act (1999) and Western Australia since 1995. Different approaches to the implementing SEA have emerged over the years, ranging from 'EIA-type' SEA that essentially mimic project-based IA procedures and are applied to plans, policies or programs (Lee and Walsh 1992); through integrative approaches that seek to work within the framework of existing developmental and approval procedures (Therivel 2013); through approaches that emphasise normative and systematic tiered approach (Fischer 2007); to SEA based on strategic-thinking (Partidario 2012). The different approaches are not mutually exclusive (Ahmed and Sánchez-Triana 2008) but offer alternative means for implementation while recognising the inherent characteristics and difficulties of strategic decision-making.

\section{Perceived shortcomings of IA}


A tool that has enjoyed such widespread global application as IA is bound to be criticised, and this has certainly been the case with IA. The theory and practice of IA has been the subject of intense debate in academic journals, particularly special issues and at IAIA conferences. For example, the need and role for SEA was addressed by Bina (2007), Cherp et al. (2007), and Wallington et al. (2007); while Fischer (2012), Morrison-Saunders et al. (2012) and Vanclay (2012) debated over the integration and proliferation of IA types; and Sánchez (2012) and Canter and Ross (2012) highlighted the importance of improving scoping as a means to improve IA and achieving better environmental outcomes. A substantial volume of literature has been written about the shortcomings of IA and the possible consequences to IA outcomes, which are summarised in Table 2.

\section{Insert Table 2 here}

Closer examination of these criticisms reveals some level of consensus regarding the nature and extent of the shortcomings. For instance, some of the limitations relate to specific aspects of IA, while others relate to more over-arching concerns. Interestingly, the widening of the scope of EIA through the introduction of SEA has been touted as a remedy to the woes of IA, specifically by better dealing with cumulative impacts and uncertainty. In Western Australia, for example, the idea of SEA was ‘sold’ to government on the pretext that it will improve decision-making and make project-level IA more effective, and indeed, there is evidence of better environmental outcomes for projects, as a result (Jenkins 2015). However, SEA has been plagued by problems that are similar to those experienced with project-level IA. Over time, SEA has diversified to the point of confusion about what it is and what it is meant to achieve (Partidario 2000). More recently, SEA has been found to fail in achieving its fundamental goals (Lobos and Partidario 2014), which echoes the troubles encountered with project-level IA. 
As well as overcoming some long-standing issues, there are several new IA challenges and, perhaps, opportunities confronting IA in the near and long-term. As Vanclay (2015) points out, IA is becoming increasingly integrated with project development, manifesting as part of corporate social responsibility and social performance practices. The role of non-governmental players, such as funding agencies and financiers, and civil 'watchdog' organisations' as quasi-regulators of development through IA is growing (Banhalmi-Zakar and Larsen 2016; Vanclay 2015). Imbedding the concepts of ecological and social resilience have emerged as a key challenge over recent years, adding another layer of complexity to IA, requiring practitioners to recognise nonlinearity, feedback loops, and stochasticity (Wenning et al. 2017). Opportunities lie in harnessing new technologies, artificial intelligence and big data applications. While artificial intelligence has been used in environmental management for several decades (Cortés et al 2000), technological advances allow the exploration, visualisation and analysis of new information, such as social media and online images which can and should play a role in social impact assessments (Sherren et al. 2017).

\section{The case for (continued) evolution}

The main arguments for improving IA through continued evolution are IA's widespread application and acceptance among environmental practitioners and its demonstrated ability to be adapted to numerous situations and jurisdictions. IA has shown a great deal of flexibility and remarkable resilience by becoming one of the most successful environmental policy innovations of our time (Macintosh 2010). IA has adapted to different regulatory and cultural contexts, while its core principles stayed the same (Sadler 2004). As a highly valued policy, IA is widely known and is generally accepted by a wide range of stakeholders, including proponents and governments 
(Glasson et al. 2012). This suggests that we should be building on its success rather than move to something radically different.

While IA has grown in popularity, it has also been changing for the better, demonstrating that gradual, evolutionary changes can be an effective force for improvement. A prime example of the ability of the evolutionary path of IA to achieve significant change has been the introduction of SEA. SEA seeks to respond to the shortcomings of project IA and has always been regarded as complementary tool, and not a replacement of project-based IA. Although there are many different approaches to SEA, the 'IA evolutionaries' see SEA as an extension of the practice of IA, albeit at a more strategic level and in a more pre-emptive manner, although they acknowledge that others may disagree with this perspective (Arts et al. 2005; Dalal-Clayton and Sadler 1998).

The evolution of IA represents a form of adaptive management, also known as a 'learning by doing' approach that originated around the same time as IA (Noble 2000). Morrison-Saunders and Arts (2004) conceptualise such evolutionary processes as forms of 'IA follow-up', whereby IA in a given jurisdiction is reviewed and evaluated (macro level) or when the instrument itself is monitored and reviewed (meta level). Evolution involves iterative processes of practicing, reflecting and changing practices to adapt to new situations and conditions. Practices change in response to learnings about what is or is not effective in reaching the required objectives, as well as when the objectives themselves change. For IA, the overall substantive objective of informing development decision making about important environmental and social issues has not changed significantly. Instead, we believe that over the years, expectations about what types of science, measurements and knowledge is required to be effective in 'doing IA' have changed considerably. This is particularly evident as IA struggles to develop effective 
measures to meet new challenges such as those captured by United Nations Sustainable Development Goals (Ruckert et al. 2017).

For IA to continue on its evolutionary path requires further examination of how existing procedures can be strengthened to overcome current limitations and how the influence of IA on the decision-making process should be enhanced. To some extent, 'IA effectiveness’ studies have been successful in guiding change, leading to numerous amendments to IA regulations in an effort to improve practices and outcomes (Glasson et al. 2012). In Australia, for example, almost all states and territories have completed major reviews of IA legislation and processes in the last decade and initiated changes. The reviews have addressed matters such as: ensuring earlier and better engagement with the community and other stakeholders; improving scoping processes; improving the quality of IA documents; adopting risk and outcomes-based approaches in IA; increasing transparency in the IA process and decision making; and providing better systems for monitoring and enforcement of approval conditions (e.g. NSW Department of Planning \& Environment 2018, Hawke 2015). These are all important matters that demonstrate how processes can be strengthened through evolutionary change.

From a pragmatist's perspective, slow, incremental changes have numerous benefits. Smaller scale changes are low cost initiatives and may be quicker to implement because they often require minimal adjustment in existing institutional arrangement. It is also easier to build support amongst politicians and other stakeholders for a series of incremental changes than to advocate for extensive change in policy and practice. At the same time, it is also less painful to undo an incremental change that proves to be detrimental, than to recover from failed radical changes, such as those that can be brought about by a revolution.

\section{The case for 'IA revolution'}


The case for revolution rests on the premise that in its current form, IA cannot progress further to fulfil its aims and meet future challenges. Undeniably, IA has been a highly popular instrument, but there are many who believe that fundamental change is needed to ensure that its fundamental goals can be achieved. According to the Principles of Environmental Impact Assessment Best Practice, (IAIA 1999), the main objectives of IA are to i) ensure that environmental considerations are explicitly addressed and incorporated into the development decision making process ii) anticipate and avoid, minimize or offset the adverse significant biophysical, social and other relevant effects of development proposals, iii) protect the productivity and capacity of natural systems and the ecological processes which maintain their functions; and iv) promote development that is sustainable and optimizes resource use and management opportunities. However, as discussed earlier, experience and research indicate that, too often, IA has become a process to account for and report on impacts of actions or proposals rather than a means to guide the design of actions or proposals. Efforts to improve effectiveness have often served to expedite IA processes rather than improve environmental or social outcomes. A review of 25 years of IA practice in the United Kingdom and Netherlands concluded that IA does not seem to be promoting any real challenge to decision-making either by proponents (about the design of projects, programs, plans), or regulators and statutory decision-makers regarding the approval of same (Arts et al. 2012). Reports on the state of the environment and human well-being indicate that the scale of the impact of human activity on the environment is unprecedented and detrimental, threatening species and ecosystems, including ecosystem services that are vital to sustaining human life (Millennium Ecosystem Assessment 2005). Those that advocate for 'IA revolution' believe these are significant 
failings that cannot be ignored further. The need for action is too urgent to rely on evolutionary change.

A revolution of IA is not concerned with remedying the individual shortcomings of IA, because such an approach is more likely to yield incremental changes that are essentially evolutionary in nature. Rather, a revolutionary approach seeks to turn current thinking of IA 'on its head' through a complete overhaul of IA's processes as well as its aims. Naturally, this would be difficult for IA stakeholders as the IA process has been ingrained in their approach to development. It may be particularly challenging for experts and practitioners for whom IA is the only form of social and environmental control they have ever known. One way to think about the IA revolution is to consider starting with a clean slate and going back to the drawing board, when anything is possible. It may be useful to begin by thinking about the nature and root of environmental and social problems, current and expected environmental and social challenges and consider a full range of possible solutions without the IA mechanism in its current form. Some examples of revolutionary thinking in IA could be:

- Ending the bureaucratic focus of IA and doing away with all or most existing IA provisions and 'starting over'. Given that the underlying rationale of IA of thinking about the consequences of actions before they are undertaken is straightforward, there is no need to rely on prescriptive regulations and bureaucracies (Thomas 2001). Instead, individuals should be empowered and encouraged to carry out IA in a system where environmental and social outcomes are given a higher status (Thomas 2001).

- Completely mainstreaming the concept of IA into all key development decision processes and rolling out capacity building/training programs targeting both government and private sector stakeholders. 
- Redesigning IA as a deliberative and inclusive process, rather than a technocratic one, as suggested in Owens et al. (2001) and others.

- Redesigning IA as an outcomes-based management tool where proposals are assessed against strategies, such as regional sustainability strategies that are based on nested adaptive systems and collaborative governance (Jenkins 2015; Jenkins 2018).

- Shifting to ecosystem services as the basis for incorporating environmental factors in decision making as was undertaken in the Millennium Assessment (Millennium Ecosystem Assessment 2005).

- Considering alternative growth path(s)/economic development framework as fundamental goals for IA, questioning sustainable development as a goal (and what it is or should be). Advocating an approach that recognises that more growth is not always the best option for long-term sustainable development and instead, decisions should centre on the overall health and net benefit to society at all scales (local, regional, national and global). This could entail the introduction of new methods of integrated socio-economic and environmental assessments that redefine the principles for decision-making.

Revolutionary reshaping of current IA systems or an entire environmental policy framework is not unimaginable or 'pie in the sky'; revolutionary proposals periodically appear in discourses in some jurisdiction. Such radical changes have recently been proposed in Australia and as the host country of IAIA19, this case is worth a closer look. The Australian Panel of Experts of Environmental Law (APEEL) recently outlined their proposal for a new federal environmental policy, where the centrepiece of the current law is the federal-level IA regulation. A number of changes are proposed, 
some of which are 'tried and tested' policies that have been implemented in other jurisdictions years ago. However, together the recommendations signify a complete overhaul of the current national environmental regulatory system, including its approach and management of IA. APEEL (2017) calls for i) re-defining environmental or sustainability goals as a nation, ii) re-attributing the responsibilities for environmental protection, including designating a role for the private sector; and developing and introducing, iii) new culturally appropriate management models for Indigenous managed areas, iv) as well as a new approach to planning ('bio-regional planning') to manage terrestrial, marine and coastal areas (APEEL 2017). The call for change comes in preparation for the 20-year review of the key Australian federal environmental law in 2019. The initiative to redesign Australian federal environmental policy is gaining momentum with support among political and community stakeholders through the creation of the Places You Love Alliance, one of the largest alliances of Australian environmental groups, and is featured in the media (Morton (2018a, b); LEAN (2017), Places You Love Alliance (2018)). Although this is just one example, it demonstrates that the idea of revolutionary thinking around environmental policy and reimagining IA certainly has a place in a $21^{\text {st }}$ century environmental policy dialogue.

Those who advocate for an 'IA revolution' do recognise the challenges associated with delivering a new system. since revolutions often create as many (if not more) problems as they solve (Dahrendorf 1997). Revolutions can also fail for various reasons, including the difficulties in agreeing over key principles and gathering support from a wide range of actors (Dix 1985; Hughes 2014). IA is well-known as a contested space between a large number of actors. Debates over whether a project should be approved are frequently conducted by vocal groups with strong opposing views while the mainstream community (i.e. 'moderates') watch on or engage in much quieter ways. 
There is also the danger that revolutions allow extremist groups (and views) to emerge, pushing out 'moderates' who generally have wider appeal and present a threat to extremist control, and leave minority groups vulnerable (Conan 2011; Hughes 2014). Thus, revolutions have highly unpredictable outcomes, often characterised by an unbalanced representation of stakeholders, favouring groups that are well organised (Conan 2011). The question is, are the risks associated with a revolution worth 'doing away with’ such a widely accepted and adopted environmental assessment tool? The ‘evolutionaries’ certainly do not think so, but we invite delegates at IAIA19 to identify and deliberate options.

\section{Conclusion: Change is needed, but what kind of change?}

Undeniably, IA has been an essential tool to drive the consideration of environmental and social issues in relation to development proposals. However, continued dissatisfaction with the outcomes of IA processes worldwide and a growing uneasiness about global problems in the $21^{\text {st }}$ century prompt reconsideration of current IA practice. What are the key merits of IA systems worth keeping? How should IA advance? In what direction should IA develop and how could this development be best delivered and facilitated? What alternatives are there to replace IA? Certainly, there are no easy answers to these questions, but we also believe they should not be brushed aside any longer. Fifty years on since IA entered mainstream environmental policy with the introduction of NEPA (1969), the organisers of IAIA19 have set the ambitious theme of 'Evolution or Revolution: Where next for Impact Assessment? Two main lines of thinking are proposed. The 'IA evolutionaries' believe that there is much value in keeping most of the elements/process of IA intact, but call for new ways to overcome the challenges and limitations. The 'IA revolutionaries' believe that the current approach to IA is profoundly flawed and IA in its current form should be replaced. They 
question the adequacy of IA theory and practice to address the environmental and social issues we now face.

Both sides of the argument are looking for evidence, analysis and insights at IAIA19. This paper seeks to provide the rationale for much needed change to IA and introduced the concept of 'IA evolution' and 'IA revolution' as the two ways forward (although we recognise and welcome discussion around other options such as a more ‘revolutionary evolution' along the lines of integration along multiple directions, for instance). We did not seek to answer the question of whether the change should be 'evolutionary' or 'revolutionary' in nature. Instead, this is a call to the IA community to consider this question and come to IAIA19 with a response, ready to debate and challenge existing norms. Your contributions will help challenge contemporary thinking about IA and we hope, can result in IA enhancements that may have not otherwise been considered. There is also the possibility that opening the doors to change may initiate new conceptual models as a type of second revolution incorporating environmental and social impacts in decision-making. A common management expression (of uncertain origin) is that 'if you do what you have always done, you will get what you have always got'. Fifty years of experience shows that a business as usual approach to IA is not sufficient. We need to change. Evolution or revolution? Now is the opportunity to put your ideas for solutions to the IA community. 
Table 1. Required contents of Environmental Impact Statement under NEPA (1969)

\begin{tabular}{|c|c|}
\hline Required contents & Explanation \\
\hline Cover Sheet & \\
\hline Summary & $\begin{array}{l}\text { A summary of the EIS, including the major conclusions, } \\
\text { area of controversy, and the issues to be resolved }\end{array}$ \\
\hline Table of Contents & Assists the reader in navigating through the EIS \\
\hline Purpose and need statement & $\begin{array}{l}\text { Explains the reason the agency is proposing the action and } \\
\text { what the agency expects to achieve }\end{array}$ \\
\hline $\begin{array}{l}\text { Description of the proposed } \\
\text { action }\end{array}$ & Description of the project or action in detail \\
\hline $\begin{array}{l}\text { Alternatives to the proposed } \\
\text { action }\end{array}$ & $\begin{array}{l}\text { Consideration of a reasonable range of alternatives that can } \\
\text { accomplish the purpose and need of the proposed action }\end{array}$ \\
\hline Affected environment & $\begin{array}{l}\text { Describes the environment of the area to be affected by the } \\
\text { alternatives under consideration }\end{array}$ \\
\hline $\begin{array}{l}\text { Environmental impact of the } \\
\text { proposed action }\end{array}$ & $\begin{array}{l}\text { A discussion of the direct and indirect environmental } \\
\text { consequences or effects and their significance and a } \\
\text { discussion of the relationship between local short-term uses } \\
\text { of man's environment and the maintenance and } \\
\text { enhancement of long-term productivity }\end{array}$ \\
\hline Unavoidable impacts & $\begin{array}{l}\text { Any adverse environmental effects which cannot be avoided } \\
\text { should the proposal be implemented and any irreversible } \\
\text { and irretrievable commitments of resources which would be } \\
\text { involved in the proposed action should it be implemented }\end{array}$ \\
\hline List of preparers & $\begin{array}{l}\text { A list of the names and qualifications of the persons who } \\
\text { were primarily responsible for preparing the EIS }\end{array}$ \\
\hline
\end{tabular}




\begin{tabular}{|l|l|}
\hline Appendices & $\begin{array}{l}\text { List of agencies, organizations, and persons to whom the } \\
\text { EIS were sent }\end{array}$ \\
\hline
\end{tabular}

Source: Adapted from NEPA (1969; 2018)

Table 2. Examples of the short-comings of IA and its consequences, from the literature

\begin{tabular}{|c|c|}
\hline Perceived short-comings & Consequences \\
\hline \multicolumn{2}{|c|}{ Problems with IA components } \\
\hline Scoping is inadequate & $\begin{array}{l}\text { IA lacks focus on important issues, IA } \\
\text { reports are too long or do not cover issues } \\
\text { of importance }\end{array}$ \\
\hline $\begin{array}{l}\text { Public participation practices are } \\
\text { insufficient and/or undermined by } \\
\text { legislation }\end{array}$ & $\begin{array}{l}\text { Fundamentally undermines the } \\
\text { expectation that the public be engaged } \\
\text { and even collaborate in decision-making }\end{array}$ \\
\hline $\begin{array}{l}\text { Cumulative impacts and transboundary } \\
\text { issues are not adequately addressed }\end{array}$ & Inability to factor in cumulative impacts \\
\hline $\begin{array}{l}\text { Assessment and consideration of } \\
\text { alternatives is poor }\end{array}$ & $\begin{array}{l}\text { Potentially superior alternatives not } \\
\text { adequately considered }\end{array}$ \\
\hline $\begin{array}{l}\text { Handling of new/emerging impacts is } \\
\text { poor }\end{array}$ & $\begin{array}{l}\text { Ineffective in responding to challenges of } \\
\text { the } 21^{\text {st }} \text { century, such as climate change } \\
\text { and aspects of Sustainable Development } \\
\text { Goals }\end{array}$ \\
\hline
\end{tabular}




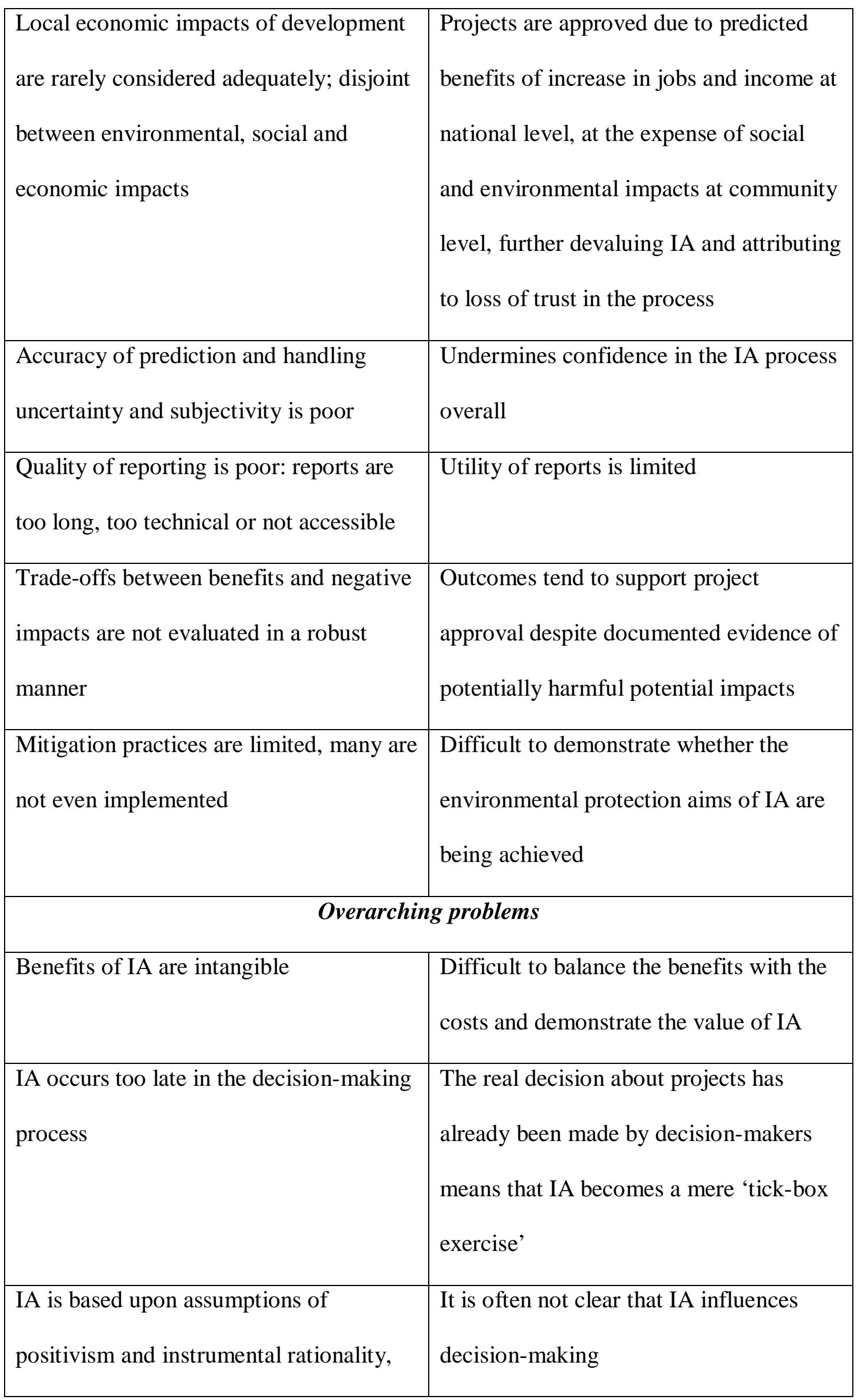




\begin{tabular}{|c|c|}
\hline $\begin{array}{l}\text { which neglects values and issues of } \\
\text { power and fails to understand how } \\
\text { decision-making works }\end{array}$ & \\
\hline $\begin{array}{l}\text { The rate of consent/approval of } \\
\text { developments is too high, implying that } \\
\text { IA has not created any fundamental shift } \\
\text { in decision-making to favour } \\
\text { environmental protection outcomes over } \\
\text { economic growth }\end{array}$ & $\begin{array}{l}\text { Fundamentally undermines the rationale } \\
\text { for IA }\end{array}$ \\
\hline $\begin{array}{l}\text { IA is done poorly, with the aim to justify } \\
\text { the projects, taking limited impacts into } \\
\text { account }\end{array}$ & $\begin{array}{l}\text { Projects that are harmful to the } \\
\text { environment, economy and society and } \\
\text { leading to the negative outcomes in the } \\
\text { short- or long-run are approved, } \\
\text { undermining the value of the IA as a } \\
\text { whole }\end{array}$ \\
\hline $\begin{array}{l}\text { Procedural requirements for IA are } \\
\text { onerous and complex, including pre- } \\
\text { application processes in some } \\
\text { jurisdictions that result in significant } \\
\text { alterations }\end{array}$ & $\begin{array}{l}\text { Increasing pressure from politicians and } \\
\text { developers for 'streamlining' IA on the } \\
\text { one hand, and proponents abandoning } \\
\text { projects on the other, because of the 'EIA } \\
\text { hurdle' }\end{array}$ \\
\hline The IA process takes too long & $\begin{array}{l}\text { Costs to the proponent (developer), } \\
\text { relevant authorities (government), } \\
\text { potentially risking the availability of } \\
\text { finance; can lead to breaking up larger }\end{array}$ \\
\hline
\end{tabular}




\begin{tabular}{|l|l|}
\hline & $\begin{array}{l}\text { projects into smaller ones that do not } \\
\text { trigger EIA }\end{array}$ \\
\hline Tiering between SEA and EIA is & Undermines the rationale for SEA and \\
problematic & practice as an integrative approach; \\
\hline There are too many different types of IAs & Lack of focus and integration between \\
& environmental, social, economic, health \\
& and other aspects \\
\hline
\end{tabular}

Sources: Arts et al. (2012), Banhalmi-Zakar (2016), Bond and Pope (2012), Bond, et al (2014), Cashmore (2004), Cashmore et al. (2004), Canter and Ross (2012), (European Commission, 2012), Fischer (2012), Glasson et al (2012), Institute of Environmental Management and Assessment (2011; 2017), Killian and Pretty (2008), Larsen et al. (2012), Larsen et al. (2013), Morrison-Saunders et al. (2012), Nitz and Brown (2001), NSW Planning and Environment (2016), Productivity Commission (2013); Quinlan et al (2016), Riley (2016), Sadler (2004), Sánchez (2012), Schmidt (2015), Sinclair and Diduck (2017), Tennoy et al (2004), Therivel et al. (2009), (Tzoumis and Finegold, 2000), Yousefi et al. (2015), Vanclay (2012), Wood (2003). 
References:

Ahmed K, Sánchez-Triana E. 2008. Strategic Environmental Assessment for policies. [accessed 9 August 2018].

https://openknowledge.worldbank.org/bitstream/handle/10986/6461/446390P UB0Stra101OFFICIAL0USE0ONLY1.pdf?sequence=1\&isAllowed=y.

Arts J, Tomlinson P, Voogd H. 2005. EIA and SEA tiering: The missing link? Position Paper presented at International Association of Impact Assessment Conference on International experience and perspectives in SEA; Sep 26-30; Prague.

Arts J, Runhaar H, Fischer TB, Jha-Thakur U, Van Laerhoven F, Driessen PPJ, Onyango V. 2012. The Effectiveness of EIA as an instrument for environmental governance: Reflecting on 25 years of EIA practice in the Netherlands and the UK. J. Environmental Assessment Policy and Management 14(4):1-40.

APEEL [Australian Panel of Experts on Environmental Law]. 2017. Blueprint for the Next Generation of Australian Environmental Law. Carlton, Melbourne. [accessed 10February 2018]. https://static1.squarespace.com/static/56401dfde4b090fd5510d622/t/59bb6fe3 f43b55b154728d29/1505456149104/APEEL+Blueprint+for+environmental+l aws.pdf.

Banerjee P, Ghose MK. 2017. A geographic information system-based socioeconomic impact assessment of the broadening of national highway in Sikkim Himalayas: a case study. Environ. Dev. Sustain. 19:2333.

Banhalmi-Zakar Z. 2016. The impact of bank lending on the environmental outcomes of urban development. Australian Planner 53(3):221-231. 
Banhalmi-Zakar Z, Larsen SV. 2016. How strategic environmental assessment can inform lenders about potential environmental risks, Impact Assessment and Project Appraisal. 33(1):68-72.

Bartlett RV. 1989. Impact assessment as a policy strategy. In Bartlett RV and Baber W F editors. Policy through impact assessment - Institutionalised analysis as a policy strategy. Westport (CN): Greenwood Press; p.1-4.

Bartlett RV, Kurian PA. 1999. The theory of environmental impact assessment: Implicit models of policy making - What makes EIA work? Policy and Politics. 27(4):414-433.

Bina O. 2007. A critical review of the dominant lines of argumentation on the need for strategic environmental assessment. Environmental Impact Assessment Review. 27:585-606.

Bond A, Morrison-Saunders A, Pope J. 2012. Sustainability assessment: the state of the art. Impact Assessment and Project Appraisal. 30(1):53-62.

Bond A, Pope J. 2012. The state of the art of impact assessment in 2012. Impact Assessment and Project Appraisal. 30(1):1-4.

Bond A, Pope J, Morrison-Saunders A, Retief F, Gunn JAE. 2014. Impact assessment: Eroding benefits through streamlining? Environmental Impact Assessment Review. 45:46-53.

Brown AL, Hill RC. 1995. Decision-scoping: making EA learn how the design process works. Project Appraisal 10(4):223-232.

Canter L, Ross B. 2012. A basic need for integration - Bringing focus to the scoping process. 32(1): 21-22. 
Cashmore M. 2004. The role of science in environmental impact assessment: process and procedure versus purpose in the development of theory. Environmental Impact Assessment Review 24(4): 403-426.

Cashmore M, Gwilliam R, Morgan RK, Cobb D, Bond A. 2004. The interminable issue of effectiveness: substantive purposes, outcomes and research challenges in the advancement of environmental impact assessment theory. Impact Assessment and Project Appraisal, 22(4):295-310.

Chanchitpricha C, Bond A. 2013. Conceptualising the effectiveness of impact assessment processes, Environmental Impact Assessment Review, 43:65-72.

Cherp A, Watt A, Vinichenko V. 2007. SEA and strategy formation theories: From three Ps to five Ps. Environmental Impact Assessment Review. 27(7):624644.

Collins English Dictionary. 2018. Revolution. [accessed 24 March 2018]. https://www.collinsdictionary.com/dictionary/english/revolution.

Cortés U, Sànchez-Marrè M, Ceccaroni L, R-Roda I, Poch M. 2000. Artificial Intelligence and Environmental Decision Support Systems. Applied Intelligence 13:77-91.

Dalal-Clayton B, Sadler B. 1998. Strategic Environmental Assessment: A rapidly evolving approach. In A directory of Impact Assessment guidelines by A Donnelly, B Dalal-Clayton, R Hughes. IIED.

Department of Planning and Environment. 2018. EIA Improvement Project. [accessed 25 February 2018] http://www.planning.nsw.gov.au/Policy-andLegislation/Under-review-and-new-Policy-and-Legislation/EnvironmentalImpact-Assessment-Improvement-Project. 
Environment and Natural Resources Committee. 2011. Inquiry into the

Environmental Effects Statement Process in Victoria. Melbourne.

European Commission. 2012. Amending Directive 2011/92/EU on the assessment of the effects of certain public and private projects on the environment.Vol. 297.

Fischer TB. 2007. Theory and practices of Strategic Environmental Assessment. London: Earthscan.

Fischer TB. 2012. Impact Assessment: There can be strength in diversity! Impact Assessment and Project Appraisal. 32(1):9-10.

Fundingsland Tetlow M, Hanusch M. 2012. Strategic Environmental Assessment: the state of the art. Impact Assessment and Project Appraisal, 30(March):3741.

Glasson J, Therivel R, Chadwick A. 2012. Introduction to Environmental Impact Assessment. 4th ed. Abingdon: Routledge.

Gronow C, Brown AL, Morrison-Saunders A. 2015. A Framework for Exploring Effectiveness. Paper presented at the IAIA15. In IAIA15 Conference Proceedings: Impact Assessment in the Digital Era; April 20-23; Florence, Italy.

Hartz-Karp J, Pope J. 2011. Enhancing the effectiveness of SIA through deliberative democracy. In New Directions in Social Impact Assessment: Conceptual and Methodological Advances. In Vanclay F and Esteves AM. Cheltenham (UK) Edward Elgar Publishing Limited.

Hawke A. 2015. Review of the Northern Territory Environmental Assessment and Approval Processes. [accessed 25 February 2018] 
https://dlpe.nt.gov.au/_data/assets/pdf_file/0011/262919/hawke-review-ofthe-northern-territory-environmental-assessment-and-approval-process.pdf. IAIA [International Association for Impact Assessment]. 1999. Principles of Environmental Impact Assessment Best Practice. [accessed 26 January 2018] http://iaia.org/uploads/pdf/principlesEA_1.pdf

IAIA [International Association for Impact Assessment. 2018. Key Citations. [accessed 26 January 2018] http://iaia.org/key-citations.php. Institute of Environmental Management and Assessment. 2011. Special Report The State of Environmental Impact Assessment in the UK. [accessed 28 July 2018]. https://www.iema.net/assets/uploads/Special\%20Reports/iema20special20rep ort20web.pdf.

Institute of Environmental Management and Assessment. 2017. Delivering proportionate EIA: A collaborative strategy for enhancing UK environmental impact assessment practice. [accessed 28 July 2018]. 28https://www.iema.net/policy/ia/proportionate-eia-guidance-2017.pdf.

Jha-Thakur U, Gazzola P, Fischer TB, Peel D, Kidd S. 2009. SEA effectiveness The significance of learning, impact assessment and project appraisal, 27(2):133-144.

Jenkins B. 2015. From Mitigation to Sustainability: Going Beyond Reactive Approaches. Paper presented at EIANZ Annual Conference; 29-30 October; Perth, WA.

Jenkins B. 2018. Water Management in New Zealand’s Canterbury Region. Netherlands. Springer Publishing Company. 
Killian J, Pretty D. 2008. Planning applications: A faster and more responsive system Final Report. London, UK.

Larsen SV, Kornov L, Wejs A. 2012. Mind the gap in SEA: An institutional perspective on why assessment of synergies amongst climate change mitigation, adaptation and other policy areas are missing. Environmental Impact Assessment Review. 33(1): 32-40.

Larsen SV, Kornov L, Driscoll PA. 2013. Avoiding climate change uncertainties in Strategic Environmental Assessment. Environmental Impact Assessment Review. 43:144-150.

Lawrence DP. 1997. The need for EIA theory-building. Environmental Impact Assessment Review. 9255(97):79-107.

LEAN [Labour Environment Action Network]. 2017. Environment Laws for the 21st century. [accessed 19 February 2018] https://d3n8a8pro7vhmx.cloudfront.net/lean/pages/308/attachments/original/1 504064600/a3_version_email_v2_a.pdf?1504064600.

Lee N, Walsh F. 1992. Strategic environmental assessment: An overview. Project Appraisal. 7(3):126-136.

Like J, Kang J, Schroth O. 2015. Prediction of the visual impact of motorways using GIS. Environmental Impact Assessment Review. 55:59-73.

Lobos V, Partidario MR. 2014. Theory versus practice in Strategic Environmental Assessment (SEA). Environmental Impact Assessment Review. 48:34-46.

Loomis JJ, Dziedzic M. 2018. Evaluating EIA systems' effectiveness: A state of the art. Environmental Impact Assessment Review. 68:29-37. 
Macintosh A. 2010. Best practice environmental impact assessment: A model framework for Australia. Australian Journal of Public Administration, 69(4):401-417.

Millennium Ecosystem Assessment. 2005. Statement from the board, Living beyond our means: Natural assets and human well-being. [accessed 20 July 2018]

https://www.millenniumassessment.org/documents/document.429.aspx.pdf.

Millennium Ecosystem Assessment. 2005. Ecosystems and Human Well-being: Synthesis. Washington DC. Island Press.

Morgan RK. 2012. Environmental impact assessment: the state of the art. Impact Assessment and Project Appraisal, 30(1):5-14.

Morrison-Saunders A, Arts J. editors. 2004. Assessing impact: handbook of EIA and SEA follow-up. London (UK). Earthscan.

Morrison-Saunders A, Fischer TB. 2006. What's wrong with EIA and SEA anyway? A sceptic's perspective on sustainability assessment. Journal of Environmental Assessment, Policy and Management 8(1):19-39.

Morrison-Saunders A, Pope J, Gunn JAE, Bond A, Retief F. 2014. Strengthening impact assessment: a call for integration and focus. Impact Assessment and Project Appraisal, 32(1):2-8.

Morton A. 2018 January 30. Our wide brown land 'The Franklin would be dammed today': Australia's shrinking environmental protections. The Guardian; Environment. https://www.theguardian.com/environment/2018/jan/30/thefranklin-would-be-dammed-today-australias-shrinking-environmentalprotections. 
Morton A. 31 January 2018. Labor branches push for new environment act and independent watchdog. The Guardian; Environment. https://www.theguardian.com/environment/2018/jan/31/labor-branches-pushfor-new-environment-act-and-independent-watchdog.

NEPA [National Environmental Policy Act]. 2018. National Environmental Policy Act Review Process. [accessed 26 April 2018] https://www.epa.gov/nepa/national-environmental-policy-act-reviewprocess\#EIS.

Nitz T, Brown AL. 2001. SEA must learn how policy making works. Journal of Environmental Assessment, Policy and Management 3(3):329-342.

NSW Planning and Environment. 2016. Environmental Impact Assessment Improvement Project: Discussion Paper. New South Wales. [accessed 2 August 2018]. http://www.planning.nsw.gov.au/ /media/Files/DPE/Discussionpapers/environmental-assessment-impact-improvement-project-discussionpaper-2016-10.ashx.

Oxford Dictionaries. 2018. Evolution. [accessed 2 July 2018]. https://en.oxforddictionaries.com/definition/evolution.

Owens S, Rayner T, Bina O. 2004. New agendas for appraisal: reflections on theory, practice, and research. Environment and Planning A. 36(11):19431959.

Partidario MR. 2000. Elements of an SEA framework- improving the addedvalue of SEA. Environmental Impact Assessment Review. 20(6):647-663. Partidario MR. 2012. Strategic Environmental Assessment better practice guide Methodological guidance for strategic thinking in SEA. [accessed 9 August 
2018].

http://ec.europa.eu/environment/eia/pdf/2012\%20SEA_Guidance_Portugal.pd f.

Places You Love Alliance. 2018. Who We Are. [accessed 4 March 2018]. http://www.placesyoulove.org/who-we-are/.

Pope J, Bond A, Cameron C, Retief F, Morrison-Saunders A. 2018. Are current effectiveness criteria fit for purpose? Using a controversial strategic assessment as a test case. Environmental Impact Assessment Review. 70:3444.

Productivity Commission. 2013. Major Project Development Assessment Processes, Research Report. Canberra, ACT. [accessed 2 August 2018]. https://www.pc.gov.au/inquiries/completed/major-projects/report/majorprojects.pdf.

Quinlan PD, Heenan EM, Govinnage SU. 2016. Independent legal and governance review into policies and guidelines for environmental impact assessments under the Environmental Protection Act 1986 (WA). Perth, WA. [accessed 2 August 2018]. http://www.epa.wa.gov.au/sites/default/files/EPA\%20Legal\%20and\%20Gove rnance\%20Review\%20-\%20Final\%20Report\%20-\%20Quinlan\%20et\%20al170516.pdf.

Retief F, Bond A, Pope J, Morrison-Saunders A. King N. 2016. Global megatrends and their implications for environmental assessment practice. Environmental Impact Assessment Review 61:52-60.

Riley S. 2016. Prioritising the environment in sustainable development: Lessons from Australian environmental impact assessment. In V. Mauerhofer V, 
editor. Legal Aspects of Sustainable Development. London: Springer Publishing Company p. 271-288.

Ruckert A, Schram A, Labonté R, Friel S, Gleeson D, Thow AM. 2017. Policy coherence, health and the sustainable development goals: a health impact assessment of the Trans-Pacific Partnership, Critical Public Health, 27(1):8696.

Sadler B. 1996. International Study of the Effectiveness of Environmental Assessment: Environmental Assessment in a Changing World. [accessed 2 August 2018]. https://www.ceaa-acee.gc.ca/Content/2/B/7/2B7834CA-7D9A410B-A4ED-FF78AB625BDB/iaia8_e.pdf.

Sadler B. 2004. On evaluating the success of EIA and SEA. In Morrison-Saunders A, Arts J. editors. Assessing impact handbook of EIA and SEA follow-up London (UK): Earthscan. p. 248-285.

Sánchez LE, Mitchell R. 2017. Conceptualizing impact assessment as a learning process. Environmental Impact Assessment Review. 62:195-204.

Schmidt OL. 2015. Environmental reviews and case studies: Ultimate streamlining: Making National Environmental Policy Act documents as small as the law will allow. Environmental Practice. 16(4):309-315.

Sheate WR. 2010. Tools, techniques and approaches for sustainability: Collected writings in environmental assessment policy and management. Singapore: World Scientific Publishing Co.

Sherren K, Parkins JR, Smit M, Holmlund M, Chen Y. 2017. Digital archives, big data and image-based culturomics for social impact assessment: Opportunities and challenges. Environmental Impact Assessment Review, 67:23-30. 
Sinclair AJ, Diduck A. 2017. Reconceptualizing public participation in environmental assessment as EA civics. Environmental Impact Assessment Review, 62:174-182.

Therivel R. 2013. Strategic Environmental Assessment in action. London: Earthscan.

Therivel R, Christian G, Craig C, Grinham R, Mackins D, Smith J, Yamane M. 2009. Sustainability-focused impact assessment: English experiences. Impact Assessment and Project Appraisal, 27(2):155-168.

Tzoumis K, Finegold L. 2000. Looking at the quality of draft environmental impact statements over time in the United States: Have ratings improved? Environmental Impact Assessment Review, 20:557-578.

Vanclay F. 2012. Integration and focus from the perspective of Social Impact Assessment: A response to Morrison-Saunders et al. 32(1):11-13.

Vanclay F. 2015. Changes in the impact assessment family 2003-2014: Implications for considering achievements, gaps and future directions. Journal of Environmental Assessment Policy and Management 17(01):1550003.

Victorian Auditor-General. 2017. Effectiveness of the Environmental Effects Statement Process. [accessed 2 August 2018]. https://www.audit.vic.gov.au/sites/default/files/20170322-EES.pdf.

Yousefi H, Noorollahi Y, Peirow S. 2015. Status of environmental impact assessment. Environmental Policy and Law. 45(6):320-325.

Wallington T, Bina O, Thissen W. 2007. Theorising Strategic Environmental Assessment: Fresh perspectives and future challenges. Environmental Impact Assessment Review. 27(7):569-584. 
Wanderer T, Herle S. 2015. Creating a spatial multi-criteria decision support system for energy related integrated environmental impact assessment. Environmental Impact Assessment Review. 52:2-8.

Wenning RJ, Aptiz SE, Kapustka L, Seager T. 2017. The need for resilience in environmental impact assessment. Integrated Environmental Assessment and Management 13(6):969-970.

Winfield M, Gibson RB, Markvart T, Gaudreau K, Taylor J. 2010. Implications of sustainability assessment for electricity system design: The case of the Ontario Power Authority’s integrated power system plan. Energy Policy. 38(8):4115-4126.

Wood C. 2003. Environmental impact assessment - A comparative review. 2nd ed. Harlow: Prentice Hall.

Zhang Y, Lu W, Guo J, Zhao H, Yang Q, Chen M. 2015. Geo-environmental impact assessment and management information system for the mining area, northeast china. Environmental Earth Sciences 74(10):7173-7185. 